\title{
USE OF REAL DEPRECIATION IN FINANCIAL MANAGEMENT OF METALLURGICAL ENTERPRISES
}

\author{
${ }^{1}$ Tomáš KUTÁČ, ${ }^{1}$ Josef KUTÁČ, ${ }^{1} E v a$ ŠVECOVÁ \\ ${ }^{1}$ VSB - Technical University of Ostrava, Ostrava, Czech Republic, EU, \\ josef.kutac@vsb.cz, tomas.kutac@vsb.cz, eva.svecova@vsb.cz
}

https://doi.org/10.37904/metal.2021.4291

\begin{abstract}
The article discusses from a financial management aspect the use of book depreciated fixed assets in the manufacturing process, which is a situation typical for companies operating in iron smelting and steel and castiron foundries. In most cases, the manufacturing plant of these businesses was acquired more than 30 years ago, and in many cases more than 60 years ago. The article explains real depreciations and defines the financial indicators which can be used to identify the level of threat to a company's financial health due to the large differences between book depreciations and the real depreciations of a fixed asset.
\end{abstract}

Keywords: Depreciations, financial health, management accounting

\section{INTRODUCTION}

If products are manufactured using book depreciated manufacturing plants, the accounting costs do not contain the depreciations of this fixed asset. If the thus undervalued costs in the accounts constitute the basis for calculating the price calculations, these calculations also contain undervalued costs in the area of depreciations, which are the only resources for self-financing the renewal of ageing manufacturing plants. An undervalued level of costs in price calculations leads to succumbing to the pressure for a lower sales price, which ensures a profit due to undervalued costs, however, this profit is not at the level that renewal of the given manufacturing plant using its own resources would ensure.

Should there be a need to renew this plant with the use of bank loans, this fact may very probably lead to an inability to repay these loans, especially in cases where the restored manufacturing plant does not offer innovated products for which the customers are willing to pay a higher price. It is possible to simulate this situation and avoid future financial distress in these cases by replacing book depreciations with real depreciations based on the true real acquisition price of the fixed asset and real period of its use.

\section{METHODOLOGY}

The information base for financial decision-making is management accounting, which distinguishes between the financial, value and economic concept of costs.

\subsection{Financial (pagatorial) concept of costs}

The financial concept of costs is applied in financial accounting. It is based on the application of a monetary form of circulation of resources according to the assumption that market-verified expenditure is the expression of costs, and that market-verified monetary compensation for the products sold is the ultimate point of the expended outputs [1]. One component of the financial concept of costs are book depreciations based on the 
true price for acquisition of a fixed asset and the depreciation period determined by the company at the start of use of this asset.

These fundamentals of the financial concept of costs are problematic from the management accounting aspect:

- In financial accounting, only those costs based on the true expenditure of money in the given accounting period (such as wages) or in the preceding periods (such as depreciations) can be shown in financial accounting.

- Valuation of costs in financial accounting (with the exception of gifts) is performed in true (historical) acquisition prices.

As a result of these principles, book depreciations with a level not corresponding to the current real time of acquisition and real depreciation period are recorded in financial accounting. Very often in practice, fixed assets are used in manufacturing which have either been fully depreciated (depreciations are zero) or which were acquired in the past for prices which do not correspond to the current prices (they were mostly far lower), and as a result, the depreciations in the accounts are undervalued. This problem from the financial management aspect is resolved in management accounting through the use of real depreciations, which are a value expression of the costs.

The principles of the financial concept of costs mean that if a loan is invested in the acquisition or renewal of a fixed asset, the "price" of this loan is expressed in interest, which has the nature of tax deductible costs (they reduce the income tax base). However, if equity is invested, the dividends can be viewed as its "price", but these do not constitute a cost in financial accounting. Outside capital appears "more expensive" than equity from the aspect of the financial concept of costs, but the generally acknowledged truth is that in reality, the opposite applies. In management accounting, this discrepancy is resolved using calculation interest.

\subsection{Value concept of costs}

The value concept of costs was developed mainly in relation to the development of cost accountancy, whose aim is to offer information for the regular running of companies. It is based on the costs which exist in reality at the time when the given performances occurred, for example, when products were being manufactured. The point of the value concept of costs is to express their real level, i.e., not the level at the time of their acquisition but at the present [2].

The value concept of costs applies primarily to costs which do not correspond with monetary expenditure at the given time, these being real depreciations or calculation interest.

Real depreciations express the current real (usual) price for acquiring a fixed asset and its depreciation period based on the assumed (real) time of its use [3]. Real depreciations should be used in cases where the accounting depreciations in the financial accounting do not correspond with the current usual acquisition price of the fixed asset and real period of its use [4]. This occurs when a book depreciated fixed asset (it has zero depreciation value) is used, or where it is not yet book depreciated, but the value of its depreciations is unrealistic since it does not correspond to the current usual price of its acquisition and real period of its use. A zero value of depreciations occurs in cases where the fixed asset was acquired at a time earlier than the period of its depreciation. The unrealistic value of the depreciation primarily results from the fixed asset being acquired at a price lower than its current usual price (for example, with the use of grants). The unrealistic value of the depreciation may also result from an only partial technical betterment (renovation) of an already depreciated fixed asset which is still in use.

Calculation interest expresses the costs for the interest-free use of equity. For example, it expresses the value which the owner requires in the form of paid-out dividends and which corresponds to the value which hey would gain by other, alternative use of this capital with a comparable level of risk. 


\subsection{Economic concept of costs}

The economic concept of costs is based on a requirement to define the level of the current real costs, which include so-called opportunity costs from lost revenues sacrificed as a result of the fact that a variant of the strategic decision was taken [5]. For example, that financial resources were used to acquire a manufacturing hall even though it was possible to lease it, or use this money in some other way, such as buying bonds or building another building and leasing it.

Under the economic concept, the costs are also called additional costs, and one typical example is calculation rent (rent of own production hall) or calculation interest (use of own money to buy bonds and not for the construction of a production hall).

Calculation rent is used primarily for own property in the form of buildings, such as a production hall which the company uses for production. The calculation rent here expresses the value which a company would gain if it leased these production halls instead of using them for its own activity. By increasing the costs through inclusion of calculation rent in the price calculation, one ensures that the calculated profit is linked causally only with the production of the given product, and not with ownership of the production hall.

But many foreign companies give concrete form to the simulation of lost profit from renting a production hall by founding two companies when building a new manufacturing company in the Czech Republic. The first company owns the production hall, which it leases to its "sister" company, which manufactures its products there, for the usual rent. In a second, similar variant, the production company performs manufacturing on leased premises, for example, in industrial zones.

\section{RESULTS}

During the financial management of a company, there is a problem from the aspect of management accounting when the pricing calculation (calculation for price negotiations) is based on book depreciations of a fixed asset in financial accounting which have significantly lower values than the real depreciations, whose values correspond to the current real prices for acquisition of the given fixed asset and truly anticipated period of use.

A price calculation using such undervalued costs does not generate sufficient pressure on the level of the sales price and therefore pressure for the generation of sufficient own resources to finance the renewal of a fixed asset. As a result, for the renewal of this asset, it is necessary to use bank loans, which must be repaid, and the interest on them must also be paid. But if this renewal does not lead to the generation of higher value for customers for which they are willing to pay a higher price, or if this renewal does not ensure a significant reduction in manufacturing costs per unit of production, there will be a significant reduction not only in profit but primarily in cash flow and thus a deterioration in the financial situation of the given company.

Financial accounting, in which book depreciations are significantly lower than real depreciations, is not a good information base for short-term and strategic financial (investment) decision-making.

To correct the difference between the book and real depreciations, calculation depreciations, which are the difference between real and book depreciations, are recommended:

Book depreciations + calculation depreciations $=$ real depreciations.

A qualified estimate to determine the correct level of real and subsequently calculation depreciations for a depreciated or undervalued asset can be made without great problems. This is based on an estimate of the usual acquisition price of the given asset (e.g., from the offer prices) and from an estimate of its period of use. It is possible to derive (simulate) the current and future situation of a company from the actual ascertaining of the annual level of these calculation depreciations, without subsequent calculation, by using the following indicators.

RealROE indicator (Real Return on Equity) 
The RealROE indicator (Equation 1) should be used in companies whose costs recorded in the financial accounting do not correspond with the real (current, usual) acquisition prices. These are primarily zero book depreciations of a fixed asset still used and which has been book depreciated or the undervalued level of book depreciations is based on the prices minus the effect of a grant or on historically low acquisition prices.

In these cases, the real return on equity indicator shows the return on equity which the owners of a company would have if the costs contained real depreciations that would ensure self-financing of renewal of the fixed asset without the need for outside resources (bank loans). This indicator also shows what the level of return will be when the fixed asset really is renewed, when the value of the new book depreciations will equal the designated real depreciations.

RealROE $=\frac{(\text { EAT-Calculation depreciations })}{\text { Equity }}$

where:

RealROE - Real return on equity after calculation depreciation

EAT - Earnings after tax

Calculation Depreciation - difference between real and book depreciations

If the value of the RealROE indicator reaches a return on equity level of approximately 0.08 more, the company generates enough of its own resources to renew the ageing fixed assets and for payouts of the usual level of dividends.

If the value of the RealROE indicator reaches a return on equity level of approximately 0.00 to 0.08 , the company does not generate enough of its own resources to renew the ageing fixed assets or for payouts of the usual level of dividends.

If the value of the RealROE indicator reaches a negative level of return on equity, the company does not generate enough of its own resources to finance the renewal of an ageing fixed asset, and as the negative value of this return increases, so too increases the problem with renewal of this asset using bank loans.

\section{RealEVA indicator (Real Economic Value Added)}

The RealEVA indicator (Equation 2) represents the net profit of the company minus the influence of real costs (primarily calculation depreciations) and minus the required return on equity (calculation interest - economic concept of costs), according to the formula [6]:

RealEVA $=E A T-C D-r_{e} \times E$

where:

RealEVA - Real Economic Value Added

$E A T$ - Earnings after tax

$C D$ - Calculation depreciation - difference between real and book depreciations

$r_{e}$ - Required return on equity

E - Equity

If the RealEVA indicator value is positive, the company generates real economic added value while ensuring its own resources for the renewal of ageing fixed assets and the required level of dividends.

If the RealEVA indicator has a zero value, no real economic added value is generated, but the company provides its own resources for the renewal of ageing fixed assets and the required level of the dividend. 
As the negative value of the company's RealEVA indicator increases, so increases the problem with ensuring funds for the renewal of ageing fixed asset and payout of dividends.

\section{RECOMMENDATION}

The results of financial accounting do not constitute a good information base for financial (investment) decisionmaking in companies already using book-depreciated fixed assets or with a depreciation level differing greatly from the current real value of its acquisition and real period of assumed use. In this case in financial accounting, there is an underestimation of the costs which should express the wear of the fixed asset (depreciations) and which are the source of self-financing for its renewal [7].

This fact can be remedied using real depreciations, but for legislative reasons they must not be used in financial accounting. It is necessary to work with them only in the context of management accounting (for example in pricing calculations).

Real depreciations can be designated on the basis of expertly estimated current real (usual) acquisition prices for the given fixed asset and estimated real period of use. For the purposes of financial management (for the needs of pricing calculations) the calculation depreciations, which are the difference between the value of the real depreciations and the book depreciations, are added to the already ascertained book depreciations.

When carrying out pricing calculations, the calculation depreciations are added to the original book depreciations, which are then spread out over individual products using the selected allocation key. One part of the calculated profit in these calculations will be real depreciations, and if their value is covered by the sales price, the basic condition for renewal of a fixed asset through self-financing will be met.

The ascertained total value of the calculation depreciations is also important for the calculation of the real values of return on equity (RealROE) and economic value added (RealEVA). The results of these indicators are important for short-term and strategic financial (investment) decision-making.

\section{CONCLUSION}

The financial conditions not just in metallurgical and foundry production are currently being adversely affected by two main factors. These are the increase in personnel costs and the hesitant yet strengthening Czech crown exchange rate. These two factors result in the funds for the renewal of outdated fixed assets being "hoovered up".

Another great problem may be the fact that undervalued book depreciations in financial accounting do not ensure funds in the long term for the renewal of fixed assets through self-financing. This fact also leads to an undervaluation of total costs in price calculations, which can then lead to an undervalued level of sales prices which do not generate sufficient profit for the renewal of a fixed asset from own resources. Moreover, this situation leads to a worse financial situation for obtaining bank loans for asset renewal and subsequent repayment from net profit.

The defining of real depreciations and the calculation depreciations based on them assists companies calculating the real return on equity, and the real economic added value from their values can be evaluated against the financial risk of restoring an ageing fixed asset.

It can also reflect the values of real depreciations in the price calculations and discover the extent to which the as yet simulated real depreciations can be covered by the current sales prices. If the prices are too low to cover the simulated depreciations, in the case of the renewal of this asset with the use of bank loans, it will be a problem for these sales prices to generate sufficient funds to repay the loan. Moreover, a loan repayment period tends to be lower than the real price of depreciation from the loan of an acquired fixed asset. This means that the value of the loan repayments will be higher than the simulated value of real depreciations. 


\section{ACKNOWLEDGEMENTS}

The work was supported by the specific university research of the Ministry of Education, Youth and Sports of the Czech Republic No. SP2021/43.

\section{REFERENCES}

[1] FIBÍROVÁ, J., ŠOLJAKOVÁ, L., WAGNER, J., PETERA, P. Manažerské účetnictví. Praha: Wolters Kluwer, 2019, p. 404.

[2] KRÁL, B. Manažerské účetnictví. Praha: Management Press, 2018, p. 791.

[3] POPESKO, B. Moderní rízení nákladů. Praha: Grada Publishing, 2009, p. 240.

[4] TASCHNER, A., CHARIFZADEH, M. Management and cost accounting: tools and concepts in an Central European context. Weinheim: Wiley-VCH, 2016, p. 304.

[5] GARRISON, R. H., NOREEN, E. W., BREWER, P. C. Managerial accounting. New York: McGraw-Hill/Irwin, 2012 , p. 762.

[6] MAŘÍKOVÁ, P., MAŘíK, M. Moderni metody hodnocení výkonnosti a oceňování podniku. Praha: Ekopress, 2005, p. 164.

[7] JANOVSKÁ, K., VILAMOVÁ, Š., VOZŇÁKOVÁ, I., SAMOLEJOVÁ, A., ŠVECOVÁ, E. a BESTA, P. Cost management in metallurgical production. Metalurgija [online]. 2012, vol. 51, no. 4, pp. 574-576 [viewed: 2021-622]. Available from: http://search.ebscohost.com/login.aspxdirect=true\&db=edsdoj\&an=edsdoj.5bc1f6bd705487989733da3409ae75d \&scope $=$ site. 